\title{
Adiposis dolorosa
}

INSERM

\section{Source}

INSERM. (1999). Orphanet: an online rare disease and orphan drug data base. Adiposis dolorosa. ORPHA:36397

Adiposis dolorosa or Dercum's disease is characterised by the development of multiple, painful, subcutaneous lipomas in association with obesity, asthenia and fatigue, and range of mental disturbances including instability, depression, confusion, dementia and epilepsy. 